\title{
Review
}

\section{Politics against domination}

\section{Ian Shapiro}

The Belknap Press of Harvard University Press, Cambridge, Massachusetts, and London, England, 2016, 288pp., ISBN 9780674743847

Contemporary Political Theory (2018) 17, S155-S159. https://doi.org/10.1057/s41296017-0132-0; published online 13 July 2017

Ian Shapiro's Politics Against Domination is both a refreshing and a disappointing book. On the one hand, it offers an impressive critical assessment of key contemporary national and global political issues, ranging from campaign funding to gerrymandering, and from military intervention to global inequality. Shapiro's masterful knowledge of world history and politics, combined with the breadth of real-world examples he uses in order to support his arguments, makes this book an excellent example of well-crafted applied political theory.

On the other hand, however, the book's strengths are somehow also its weaknesses. Shapiro aims to offer a thorough critique of domination, both at the national and global levels. And domination in contemporary political theory (at least in the Anglo-American analytical tradition) is synonymous with republicanism. It is therefore surprising that Shapiro does not provide any detailed or sustained account of contemporary theories of republicanism, and fails to engage, for example, with the works of such influential republican thinkers as Frank Lovett (2010) and Cécile Laborde (2008). Even Philip Pettit (1997; 2012; 2014), the main exponent of contemporary republicanism, is only cited by Shapiro a handful of times, and his work is only briefly discussed.

Relatedly, it is not possible, for any reasonably informed contemporary scholar of political theory, to fully assess the book's argument without a clear understanding of what Shapiro means by domination. For example, he defines it 'as involving the avoidable and illegitimate exercise of power that compromises people's basic interests' (p. 5). Yet neither this brief definition nor the more extensive discussion of domination offered in the remainder of Chapter 1 clarifies, for example, whether Shapiro sees domination as the 'arbitrary' (Pettit, 1997) or 'uncontrolled' (Pettit, 2012) interference by others, as Pettit does. In truth, Shapiro does mention Pettit's definition, but only for critical purposes. More specifically, he rejects Pettit's view that 'merely having the capacity to interfere in the lives of others at will constitutes domination of them' (p. 21), and claims that this definition is flawed because '[it] confuse[s] the potential for something with its occurrence'

(C) 2017 Macmillan Publishers Ltd. 1470-8914 Contemporary Political Theory Vol. 17, S3, S155-S159 
(p. 21). Some agents, he argues, may have the power to interfere with the lives of others, but only have an interest in dominating some of them. Yet it is not clear why this should affect an account of domination. In one of his examples, for instance, Shapiro claims that "[t]oday the United States has the capacity for arbitrary interference in Cuba, Mexico, Canada, and Lesotho, but it stands in very different relations to them from the standpoint of domination' (p. 21). Yet we all know that should circumstances change, the United States (US) would probably have the power to interfere with the life of virtually any country in the world, as it did in the past with Korea, Vietnam and Iraq, among others. The mere fact, for example, that the US may no longer be interested in dominating Vietnam, does not eliminate the fact that the US has the power to (and the current structural features of the international system would probably allow it to) interfere with its political and economic life, should it deem that necessary. If we abandon the distinction between potential and actual interference, much of the critical power of the republican ideas of domination and non-domination is lost.

Relatedly, by overlooking Laborde's (2008) work, Shapiro fails to assess how domination may manifest itself in increasingly multicultural societies. His example of 'a playground bully [who] is able to beat up any of the smaller children but is widely known only to beat up black children' (p. 21) is not just an isolated case but may reflect broader power asymmetries within increasingly 'ethnicized' (Laborde, 2008 , p. 230) societies, where members of certain minorities are victims of especially strong forms of domination, manifested in physical violence or, perhaps more often, in various forms of verbal and symbolic hatred.

One of the themes that runs throughout the book, and especially in Chapters 2 and 3 (which are dedicated to issues of domination at the national level), and in Chapter 7, is electoral design. Given Shapiro's intention to focus on real-world politics and institutions, this is not surprising. Moreover, it is a welcome analysis, given the dearth of examinations of electoral systems in contemporary political theory. Shapiro argues that majoritarian democracy, involving majority rule and alternation of power, is a better antidote to domination than various forms of constitutionalism and separation of powers. When it comes to electoral design, he prefers single member plurality (SMP) electoral systems to proportional representation (PR) ones. The latter, he claims, encourage the formation of single-issues factional parties which, while being more responsive to voters' interests before elections, risk becoming both unduly influential and highly unaccountable at the post-election stage, when the formation of coalition governments is almost always inevitable. Even very small parties, Shapiro argues, can be decisive in PR systems, if their votes (and seats) are necessary for the formation of coalition governments. Furthermore, once they have entered a coalition, parties in a PR system 'can fingerpoint and blame one another for unpopular government policies, arguing that their hands were tied - which they might in fact have been' (p. 175). This problem, Shapiro argues, reduces parties' accountability but can be resolved by ensuring (via 
SMP electoral systems) that coalitions are decided before elections (within big tent parties), so that citizens can vote for them and hold them accountable afterwards.

I find these claims highly problematic. For a start, recent history in the United Kingdom (UK) shows that SMP electoral systems are not a secure antidote to postelection coalitions, as shown by both the 2010 and the 2017 general elections. However, even setting aside the UK case, which some would probably consider an anomaly, it is not clear that PR generally has the effects that Shapiro suggests. First, it is rarely the case that post-election coalitions significantly undermine the representativeness and accountability of elected parties and partisans. When they vote for their preferred party under a PR system, voters know that that party will almost certainly not be able to govern on its own. Furthermore, they normally also know, based on information about the party's history and ideology, that that party is likely to enter a coalition not with any other party but only with those parties whose ideology and political platform most closely resemble its own. Relatedly, they also know that their preferred party's platform will somehow have to be diluted if the party enters a coalition government, though exactly how is something that, admittedly, cannot always be foreseen.

Yet, even in the latter case, one need not renounce PR in order to guarantee parties' representativeness and accountability. For example, when the German Social Democratic Party (SPD) decided to enter a post-election grand coalition with Angela Merkel's Christian Democratic Union (CDU) in December 2013, that decision was taken on the basis of an internal ballot in which $76 \%$ of the party's members voted in favour. One could therefore argue that mechanisms of intra-party democracy, especially if inclusive and accompanied by various forms of intra-party deliberation, may complement parties' pre-electoral representativeness and accountability, and ensure that no coalition deal neglects voters' (and members') interests.

Another important topic discussed by Shapiro is campaign funding. Regulation of private campaign financing, Shapiro argues, is normally objected, especially in the US, by appealing to freedom of speech. Yet, he rightly argues, '[i]t is just not true...that limiting how much money a person or a group can spend on political communication during a campaign "necessarily" restricts "the number of issues discussed" or "the depth of their exploration" [since]... unlimited expenditures during political campaigns fosters scarcity by generating arms races in which the wealthy can perpetually outspend their opponents' (p. 96). While persuasive, this claim is not accompanied by a more thorough reflection on the meaning and moral justification of freedom of speech. A more thorough investigation, paying more attention to the legal and philosophical literature on free speech, would have strengthened the argument.

In Chapters 5 and 6, Shapiro tackles issues of global politics. In the former, he rejects the idea of a world government and invokes more realistic measures, including a global minimum wage. Yet more space could have been devoted to a discussion of the dominating power of multinational corporations, which

(C) 2017 Macmillan Publishers Ltd. 1470-8914 Contemporary Political Theory Vol. 17, S3, S155-S159 S157 
increasingly have the power to interfere with the life and liberty of both state and non-state actors (Laborde, 2010; Pettit, 2012). For example, would Shapiro justify introducing measures against the formation of economic monopolies, or against trade-distorting subsidies?

In Chapter 6, Shapiro examines the moral permissibility of military intervention to overthrow oppressive regimes. He defends the formula '[s]top the bully without becoming one' (p.170). States, that is, should aim to 'empower those who resist domination without themselves seeking to dominate' (p. 171). The key criteria that any legitimate intervention must present, according to Shapiro, are the following: 'invitation by the legitimate government of the invaded country, supplemented, where possible, by authorization in a credible international forum; enforcement by a large and diverse coalition; and proportional restraint to limit the intervention to what is needed to achieve the authorized objective' (p. 147). Some engagement with the just war theory literature, only mentioned by Shapiro once in a footnote (p. 256 n. 192), would have helped to contextualize his argument within the broader contemporary debates.

Finally, Shapiro's scepticism regarding a global government also makes him doubt the feasibility of 'global political parties' (p. 179), especially in view of the 'less than prepossessing experience with transnational parties in the EU [European Union]' (p. 179). Shapiro's quick dismissal of EU transnational parties is slightly unfair. Once again, a greater engagement with recent theoretical debates (e.g. White, 2014) would have enabled the reader to better assess his conclusion. Moreover, his implicit assumption seems to be that transnational parties presuppose a world government and global institutions. However, such parties may sometimes contribute to creating (rather than simply relying on) such institutions, as for example the history of Christian Democracy in post-WWII Europe shows (White, 2014).

In summary, this is a very engaging book, rich with insights and empirically informed. Yet its failure to engage with key theoretical issues somehow detracts from its quality and its potential contribution to broader debates in contemporary political theory.

\section{References}

Laborde, C. (2008). Critical Republicanism: The Hijab Controversy and Political Philosophy. Oxford: Oxford University Press.

Laborde, C. (2010). Republicanism and global justice: A sketch. European Journal of Political Theory 9(1): 48-69.

Lovett, F. (2010). A General Theory of Domination and Justice. Oxford: Oxford University Press.

Pettit, P. (1997). Republicanism: A Theory of Freedom and Government. Oxford: Oxford University Press. 
Pettit, P. (2012). On the People's Terms: A Republican Theory and Model of Democracy. Cambridge, UK: Cambridge University Press.

Pettit, P. (2014). Just Freedom: A Moral Compass for a Complex World. New York: W.W. Norton \& Company Inc.

White, J. (2014). Transnational partisanship: Idea and practice. Critical Review of International Social and Political Philosophy 17(3): 377-400.

Matteo Bonotti

Cardiff University, Cardiff, Wales CF10 3AX, UK

bonottim@cardiff.ac.uk

(C) 2017 Macmillan Publishers Ltd. 1470-8914 Contemporary Political Theory Vol. 17, S3, S155-S159 S159 